INTERNATIONAL JOURNAL OF MULTIDISCIPLINARY RESEARCH AND ANALYSis

ISSN(print): 2643-9840, ISSN(online): 2643-9875

Volume 04 Issue 07 July 2021

DOI: 10.47191/ijmra/v4-i7-07, Impact Factor: 6.072

Page No.- 913-917

\title{
Lexical-Semantic Analysis of Various Component Phraseology in Rashod Nuri Guntekin's Novels
}

\author{
Muazzama Foziliya \\ Student Faculty of Turkic Studies Tashkent State University of Oriental Studies
}

\begin{abstract}
This article discusses one of the most interesting scientific disciplines in world linguistics, the study of phraseology. Research in Uzbek and Turkish linguistics has been commented on. In Uzbek linguistics, attention is paid to the issue of grouping according to the meaning, lexical, methodological and semantic features of phraseology, and some shortcomings are discussed. Particular emphasis is placed on the semantic classification of phraseologies, the interpretation of complex phrases. It is explained by the scientific views of Turkish linguists on phraseology, the terms "idiom", "expression". It is also argued that the common features of phraseology in all languages of the world are the same, and in the language of writers the use of phraseology to give national identity. Lexical-semantic analysis of phraseologies and phrases refers to the national language, which reflects similarities in the worldview, religion and customs of the speaking population. At the same time, the phraseology used in the Ottoman period in the Turkish language was analyzed lexically and semantically. For this purpose, the author Rashod Nuri Guntekin's novels "Çalıkuşu” (Cholikushi), "Bir Kadin Düşmanı" (An Enemy of a Woman) were chosen as a source. In his novels, Rashod Nuri Guntekin notes that the protagonists used a lot of rhetoric to ensure nationalism in their speech, and that no other can be used in their place. Praising the author's writing skills, the phraseology in his novels is analyzed lexically and semantically based on certain components. Accordingly, the expressions used by the author in the two works are classified according to a certain system. Author Rashod Nuri Guntekin's novels, on the other hand, contain a variety of components. Turkish writer Rashod Nuri Guntekin's novels "Cholikushi" and "An Enemy of a Woman" contain various component expressions and the author uses them to express different meanings.
\end{abstract}

KEYWORDS: phraseology and its types, pure linguistic analysis, phraseology of the period, phraseology in some works, groups of phraseology, semantic aspect, complex phraseology, lexical-semantic analysis, idiom, novel.

\section{INTRODUCTION}

One of the most interesting fields of study in world linguistics is the study of phraseology. There is a lot of research on this. Uzbek linguists Sh.Rakhmatullaev, U.Tursunov, H.Berdiyorov, H.Doniyorov, M.Mirzaev, A.Abdunazarov, A.Khojiev, M.Sadikova studied phraseology from a purely linguistic point of view. Linguists such as A.Abdullaev, S.Solikhojaeva, S.Goibov, M.Sadriddinova, B.Yuldashev studied phraseology of a certain period in fiction. Y.D. Pinkhasov, A.Sh. Shomaksudov, M.Khusainov, I.Kochkartoev, I.A.Umarov, H.Kahhorova, B.Turdialiev in their scientific works commented on phraseology in the works of some masters of words.

The issue of grouping phraseologies according to their meaning, lexical, methodological and semantic features has always been relevant. Linguists H.Berdiyorov, R.Rasulov and B.Yuldashev divided phraseological units into three groups according to their meanings, lexical and methodological features [17.4-7]: 1) lexical-phraseological units; 2) real phraseological units; 3) phraseological stamps. In this classification, the sharp differences between the phraseologies are not clearly defined, and there is also confusion in the division of phraseological groups into types within them. Some non-phraseological lexical units are also listed as phrases. However, despite the above shortcomings, this classification and the dictionary compiled by the authors are of great scientific importance.

\section{THE MAIN FINDINGS AND RESULTS}

Well-known Shavkat Rakhmatullaev interpreted phraseologies as semantic phraseological integrity and phraseological confusion [18.74]. However, Rakhmatullayev's classification does not reflect a number of phraseologies related to national traditions, religious beliefs, as well as complex ones. Linguist U.Lafasov in his dissertation “Expression of subjective modality in dialogic speech" [19.81-139]] distinguished a number of complex phraseologies as a means of expressing subjective modality. 
Lexical-Semantic Analysis of Various Component Phraseology in Rashod Nuri Guntekin's Novels

The act of connecting words together to form a phrase involves the free joining of parts of speech. Phraseological expressions of stable compounds have a different character, they have a grammatical-semantic integrity, inseparability, not a free connection [20.26]. Therefore, there is a big difference in their structure and meaning. A phraseological unit is a lexical unit consisting of more than one lexical base, which is structurally equivalent to a compound or a sentence, corresponding to the content of the word, and has a figurative meaning as a whole This definition fully reflects the scientific nature of phraseology.

Writer Rashod Nuri Guntekin's novels "Cholikushi" and "The Enemy of a Woman" used a lot of rhetoric to ensure the nationalism of the protagonists. The author has found and used these language units in such a way that one phrase cannot be replaced by another. The expressions used in the author's two works are classified according to a certain system. Writer Rashod Nuri Guntekin's novels often contain statements with different components:

1. “Gönül”(psyche) component expressions: gönül eğlendirecek (to cheer up), gönlün rahat etsin (be happy), gönüller şen olsun (be calm).

1) in a sarcastic way. For example: O haldesi var mı? Mesut dul, lüksüne, fantezisine uşaklık edecek yeni bir kısmet avlayıncaya kadar benim kuzenle dalga geçecek, gönül eğlendirecek... ("Çalıkuşu" (Cholikushi). P. 38). (Is he still alive? The happy widow, in her luxury, in her fantasy, kneels before me, until she finds a salty wolf.)

2 ) in the context of an order. For example: Fakat artık büyümeye başlamış bir genç kız hiç fark edemez... Hadi gönlün rahat etsin...( "Çalıkuşu" (Cholikushi). P. 43)( But a growing young girl makes no difference. Go, please...)

3 ) in the context of negligence. For example: Ben, o Zeyniler'de de mesut olmasını bileceğim. Gönüller şen olsun! (P. 156). (I also find happiness in Zaynis. Let it be, let their hearts be full!)

2. "Yürek"(heart) component expressions: yüreğim oynuyor (my heart was pounding), içine sinmemiş (did not fit in his heart), yüreği de beraber eriyor (as his heart melted together), kalbim de parça parça oluyordu (my heart was pounding too).

1) excitement-passion-emphasis content. For example: Kuzenimin birdenbire ona yürüdüğünü, ellerini kaldırdığını görüyorum... Yüreğim oynuyor, "nihayet aklı başına geldi, bu fena kadına güzel bir tokat atacak!" ("Çalıkuşu" (Cholikushi). P.40). (Suddenly I saw my uncle walking towards him, raising his hands... My heart was pounding, I thought, "Finally he came to his senses, he will slap this bad wife".)

2) compression-emphasis content. For example: Annemi yabancı bir toprakta bıraktıktan sonra, istanbul'a dönmek babamın içine sinmemiş...( "Çalıkuşu" (Cholikushi).P. 16). (After we put my mother in a foreign land, returning to Istanbul did not fit in my father's heart...)

3) emotion-emphasis content. For example: Fakat hakikaten tarifine imkân yok... insan, onları ağzında eritirken yüreği de beraber eriyor ("Çalıkuşu" (Cholikushi). P. 51). (When a man melts them in his mouth, his heart melts together.)

4) content of oppression. For example: Benim kalbim de parça parça oluyordu ("Bir Kadin Düşmanı" (An Enemy of a Woman). P. 126). (My heart was pounding too.)

3. "Göz"(Eye) component expressions: gözüne kestirmişti (had taken into account), gözüm yıldığı (my eyes are burning), gözlerim parlar (my eyes glow), gözlerine dikili (staring into his eyes).

1) in the context of comments. For example: Bu çığlık ve telaştan gözüm yıldığı için artık havuza girmeye cesaret edemiyor, yüzükoyun,... ("Çalıkuşu" (Cholikushi). P. 16-17). (I can't wait to go to the pool because of these sighs and tears).

2) joy-emphasis content. For example: Ne zaman derin bir üzüntüye kapılsam gözlerim parlar, tavır ve hareketlerim neşelenir, içim içime sığmaz olur ("Çalıkuşu” (Cholikushi). P. 19). (When I grieve, my eyes light up, my face opens, I can't fit on my skin.)

3) coolness-emphasis content. For example: Niyetim, gözlerim gözlerine dikili, ona baş eğdirip neticeye kadar bu küstah ve zalim alaya devam etmek ("Çalıkuşu" (Cholikushi). P.79). (My intention was to keep this sharp poisonous satire on until I stared into his eyes and bowed to him)

4. "Ayak"(Foot) component expressions: ayak basmasına tahammül edemem (I do not believe).

1) in the context of emphasis. For example: Bilirsiniz ki ben Çalıkuşu'yum. Ağaçlar benim mülkümdür. Oralara benden başkasının ayak basmasına tahammül edemem ("Çalıkuşu" (Cholikushi). P. 41). - (You know, I'm Cholikushi. Trees are my universe. I don't believe anyone other than me would set foot in these places.)

5. "Içim"(Happy) component expressions: içim içime sığmaz olur (I will be very happy).

1) very happy. For example: Ne zaman derin bir üzüntüye kapılsam gözlerim parlar, tavır ve hareketlerim neşelenir, içim içime sığmaz olur ("Çalıkuşu" (Cholikushi). P. 19).( When I am in great sorrow, my eyes shine, my face opens, I am very happ.)

6. "Sır"(Secret) component expressions: sır saklamaya alışmış (keep secret).

1) comment content. For example: ...büyük bir adam gibi sır saklamaya alışmış olmamdandır. ("Çalıkuşu” (Cholikushi)P.13). (I learned to keep secrets like adults.)

7. "Şaşkına"(confused) component expressions: şaşkına çevirirdim (confused). 
Lexical-Semantic Analysis of Various Component Phraseology in Rashod Nuri Guntekin's Novels

1) acknowledgment content. For example: Sevdiğim insanın üstüne bir canavar yavrusu gibi atılır, kulaklarını ısıır, yüzünü tırmalar, tartaklaya tartaklaya şaşkına çevirirdim ("Çalıkuşu" (Cholikushi). P. 20). (I would shoot at my loved one like an animal, stretch out his ears, scratch his face, push and confused.)

8. "Anne"(mother) component expressions: annesinin dizi dibinde büyümüş (grew up under the skirts of his mother).

1) in a sarcastic way: For example: Necmiye, neyse ne... işin nihayetinde o, annesinin dizi dibinde büyümüş, yumuşacık, sıcak bir külkedisiydi ("Çalıkuşu” (Cholikushi). P. 28). (As for Najmiya ... In short, she was a soft, pious domestic cat who grew up under her mother's skirts.)

9. "Yazık" (Pity) component expressions: yazık olur (will be very bad), yazık zavallıya (unhappy fate).

1) warning-emphasis content. For example: - Tüy gibi hafifsin abla, dedim. Çırpınacak olursan boylu boyumuza düşeriz, ikimize de yazık olur ("Çalıkuşu" (Cholikushi). P. 60). - (If you stumble, we'll fall, and it will be very bad for both of us.)

2 ) in the context of emphasis. For example: - Niçin yalan söyleyeyim, öyle? Münevver, bu haberden sonar katiyen yaşamaz. - Yazık zavallıya (P. 107). - What do I do by lying, yes. Munawwar will never live after this news. "The poor man's unhappy fate".

10. "Keyf”(Mood) component expressions: keyfimi kaçırdı (to disappoint).

1) the content of the emphasis. For example: Kâmran'ın gelmesi hakikaten keyfimi kaçırdı ("Çalıkuşu”. (Cholikushi) P. 70). (Comron's arrival really made me disappoint.)

2) in the context of protest. For example: Kâmran'ın gelmesi hakikaten keyfimi kaçırdı (P. 70). (Comron's arrival really blurred my taste.)

11. "Kim" (Who) component expressions: kim bilir (Who knows).

1) ambiguity-emphasis content. For example: a) Kim bilir, ileride belki büsbütün bile gelirim, değil mi? Hayat bu, her şey mümkün... ("Çalıkuşu” (Cholikushi). P. 391-392).( Who knows, one day I'll be back one day, right? Life can be anything ...) b) Kim bilir nekadar dargınsın... ("Bir Kadin Düssmanı" (An Enemy of a Woman). P. 16). (Who knows how upset you may be.)

12. "Saadet" (Happines) component expressions: saadetten öldürecek (to burst with happiness).

1) in the context of comments. For example: Binaenaleyh Vesime ile evlendiği gün onu saadetten öldürecek bir gün olacakti ("Bir Kadin Düsmanı" (An Enemy of a Woman).P. 125). (Consequently, on the day he marries Vasima, he must burst into tears of happiness)

13. "Işime"(Soul) component expressions: işime yarardı (it would enter my soul).

1) content of satisfaction. For example: Çalıkuşu benim hem hoşuma gider, hem işime yarardı ("Çalıkuşu” (Cholikushi). P. 23). (I also liked "Cholikushi", because the name was often in my heart)

14. "Kan"(Blood) componenet expression: kanıma dokunuyordu (get very angry).

1) in the context of anger. For example: Erkek akrabalar ve konu komşu tarafindan ikide birde ballandırılan meziyetleri fena halde kanıma dokunuyordu ("Çalıkuşu” (Cholikushi). P. 28). (I was very angry when my male relatives and neighbors praised him as a good guy.)

15. "Dil" (Soul) componenet expression: dilinin ucunda (at the tip of the tongue).

1) in the context of threats. For example: - Peki, dedim. Yalnız dilinin ucunda bir şey var ki mutlaka söylemezsen bu sefer ben uyuyamayacağım ("Çalıkuşu” (Cholikushi). P. 70). - (Well, but there's something on the tip of my tongue, and if I don't say it now, I won't be able to sleep today, I said.)

16. "Bereket" (Abundance) componenet expression: bereket versin (find abundance).

a) in the context of prayer. For example: Bereket versin Aziz Eniştem, misafirine fena halde kancayı takmıştı ("Çalıkuşu" (Cholikushi). P. 70).( Aziz hit the guest well)

17. "Birdenbire"(Suddenly) componenet expression: birdenbire sustun (to remain silent).

1) in a sarcastic way. For example: Müjgân: - Ne o, sen birdenbire sustun, dedi ve başını çevirince on, on beş adım ileride Kâmran'ı gördü ("Çalıkuşu" (Cholikushi). P. 72). (Mujgon: - Yes, suddenly you fell silent? He turned his head and saw Comron coming ten or fifteen paces away.)

18. "Hatırın" (Remember) componenet expression: hatırın kalmasın (don't be sad).

1) comfort-emphasis content. For example: - Hatırın kalmasın ama, seninle hiç olmaz diyorum. Bu tombul yanacıkları kanatırsak ne olur? ("Çalıkuşu” (Cholikushi). P. 78). (- Don't worry, I'll fly you too. But wouldn't it be a shame if we blew up that chubby face? I said.)

19. "Canının" (Soul) component expression: canının sıkıldığı (his soul hurt).

1) embarrassment in the sense of emphasis. For example: Bu hareketime, canının sıkıldığı anlaşılıyordu ("Çalıkuşu" (Cholikushi). P. 82). (It was obvious that my heart ached from this act.)

20. "Fal" (Divination) component expression: fal taşı gibi açılmıştı (to be vigilant). 
Lexical-Semantic Analysis of Various Component Phraseology in Rashod Nuri Guntekin's Novels

1) in the sense of being vigilant. For example: - Ne söylüyorsun, abla! Gözlerim fal taşı gibi açılmıştı ("Çalıkuşu" (Cholikushi). P. 62). ("Really, sister! I woke up.")

21. "Mahzun" (Sad) component expression: mahzun oluyorum (to be upset):

1) to be embarrassed. For example: Biraz durakladıktan sonra cevap verdim: - Gündüz söylediğin münasebetsiz lakırdıyı aklımdan çıkaramıyorum, mahzun oluyorum ("Çalıkuşu" (Cholikushi). P. 62). (After some hesitation, I replied, "I can't remember what you said during the day, I'm embarrassed".)

22. "Sahiden"(Really) component expression: sahiden seviyorsun (to fall in love).

1) excitement content. For example: - Zavallı Feride'ciğim. Sen, Kâmran'ı sahiden seviyorsun, dedi ("Çalıkuşu" (Cholikushi). P. 64). - (Poor Farida! Komron really fall in love you!)

23. "Gec"(Late) component expression: geceyi hatırlamıyorum bile (greetings to the past).

1) content to spread goodness. For example: - Geceyi hatırlamıyorum bile, dedim ve tekrar kaçtım ("Çalıkuşu" (Cholikushi). P. 66). - (Blessings for the past, I said, and ran away again.)

24. "Sabır" (Patience) component expression: sabırsızıktan çıldırtacak (which makes one's patience odd).

1) protest content. For example: Fakat Müjgân Abla insanı sabırsızıktan çıldırtacak kadar mızmız ("Çalıkuşu" (Cholikushi). P. 66). (Only Sister Mujgon slows down to the point where the one's patience odd.)

25. "Akl" (Intelligence) component expression: aklım karıştı (to be surprised).

1) embarrassing content. For example: - Çok, kızım, seni görünce aklım karıştı, onu görüyorum sandım. Allah toprağı kadar ömür versin sana ("Çalıkuşu” (Cholikushi). P. 117). - (Very, my daughter. I was amazed to see you, I thought umi. May my God grant you a long life.)

26. "Hoş" ( Pleasant) component expression: hoş geldin (welcome).

1) in the context of service-emphasis. For example: Bir hademe beni Nazır'ın yanına götürecek, o da diplomamı görür görmez; "Hoş geldin hanım kızım. Biz de senin gibileri bekliyorduk" diye beni,... ("Çalıkuşu" (Cholikushi). P. 121). (When he saw my diploma, he said, "Welcome, my white girl. We were waiting for people like you, "he said.)

27. "Cesaret" (Courage) componenet expression: cesaret edemiyor (to be embarrassed).

1) the content of fear and embarrassment. For example: Kimseye bir şey sormaya cesaret edemiyor, şaşkın şaşkın etrafıma bakınıyordum ("Çalıkuşu" (Cholikushi). P. 121). (I was embarrassed to ask anyone, and I looked around.)

28. "Baş"(Head) componenet expression: başımıza gelen (pain upon pain).

1) cho'chish-ta'kid mazmuni. For example: Peçenin altında, korku ile dilimi çıkardım. Bu, böyle olursa, efendisi, kim bilir ne olacak? Vay başımıza gelen, diye düşündüm ("Çalıkuşu” (Cholikushi).P.122). (I pulled my tongue out, amusing myself inside my quilt. "When the servant is so, how is his master? Wow, pain upon pain, I thought.)

29. "Sabah" (Morning) componenet expression: sabah şerifler hayrolsun (good morning).

1) in good faith. For example: Kapı hafifçe vuruldu. Hacı Kalfa'nın sesi: - Sabah şerifler hayrolsun hocanım, sen yine erkencisin bugün, dedi ("Çalıkuşu” (Cholikushi). P. 134). (There was a slow knock on the door, and then Haji Khalfa said, "Good morning, my dear daughter".)

30. "Kurban" (Victim) componenet expression: kurbanın olayım (become a victim).

1) the content of love for the person. For example: "Kulun kurbanın olayım efendiciğim, öldür beni, lâkin bırakma, boşama!..." (P. 158) - (Be a slave, be a victim, dear husband, if you kill me, kill me, but don't leave me, don't leave me! ..)

31. "Tövbe" (repentance) componenet expression: tövbe olsun (if I lose).

1) the content of the oath. For example: "Tövbe olsun, hani şu ayrılık bana akşamki tekmeden ağır geldi doğrusu!" dedi (P. 161). - ("If I lose you, it's worse than the kick I took yesterday")

32. "Himmet" (benevolance), componenet expression: himmetleri hazır nazır olsun (God bless).

1) memorization content. For example: - Ben de bilmem kızım, bu köy eskiden onlarınmış. Şimdi mezarlarından gayri bir şeyleri kalmamış. Himmetleri hazır nazır olsun, erenlerdenmiş (P. 167-168). - (I don't even know, my daughter, this village has always belonged to them. Now there is nothing left but the towers. God bless them.)

33. "Şükür" (thank you) component expression: çok şükür (Thank goodness).

1) content of consent. For example: - Kurtuldun Homongolos... Çok şükür kurtuldun...( "Bir Kadin Düşmanı" (An Enemy of a Woman). P. 83). - (You got rid of Homongolos... Thank goodness you got rid of it.)

\section{CONCLUSION}

In conclusion, the phraseology of all the languages of the world is united by a common feature, but differs in that each national language has a unique feature. In the novels of Turkish writer Rashod Nuri Guntekin "Cholikushi", "An Enemy of a Woman" "gönül”(psyche), "yürek"(heart), "göz"(eye), "ayak”(foot), “içim"(soul), "sır"(secret), "şaşkına”(confused), "anne”(mother), 


\section{Lexical-Semantic Analysis of Various Component Phraseology in Rashod Nuri Guntekin's Novels}

“yazık"(pity), "keyf"(enjoyment), "kim"(who), "saadet"(happiness), "işime"(myjob), "kan"(blood), "dil"(soul), "bereket"(abundence), "birdenbire"(suddenly), "hatırın"(remember), "canının"(soul), "fal”(fortune), "mahzun"(sad), "sahiden"(really), "gec"(late), "sabır"(patience), "akl”(intelligence), "hoş"(welcome), "cesaret"(courage), "baş"(head), "sabah"(morning), "kurban"(sacrifice), "tövbe"(repentance), "himmet"(benevolance), "şükür"(thank you) component statements were encountered and they expressed different meanings.

\section{REFERENCES}

1) H.Berdiyorov, R.Rasulov, B.Yuldashev. Materials from Uzbek phraseology. Samarkand :, The first part,1976, P. 4-7.

2) U.Tursunov, J.Mukhtorov, Sh.Rahmatullaev. Modern Uzbek literary language. Tashkent: 1992, P. 74.

3) U.Lafasov. Candidate's dissertation “Expression of subjective modality in dialogic speech". Tashkent:,1996, P. 81-139.

4) A.Gulamov, M.Askarova. Modern Uzbek literary language (syntax). Part 2. Tashkent: “Teacher" 1987, P. 26.

5) Sh.Rahmatullaev. Our speech is beautiful. Tashkent: Science, 1970, P. 56.

6) Rashod Nuri Guntekin. Choliqushi. Translator Mirzakalon Ismaili. Tashkent: Editor-in-Chief of Sharq Publishing and Printing Joint-Stock Company. 2014.

7) Rashod Nuri Guntekin. The woman is the enemy. Shed leaves. Boboxon Muhammad Sharif. Tashkent: Publishing House. 2013.

8) Rashod Nuri Guntekin. The novel "An Enemy of Women". Inkılar Bookstore Publishing Industry and Trade Inc. Yenibosna Istanbul:.2016.

9) "Turkish dictionary" (from the website).

10) A. Hodjiev Explanatory Dictionary of Linguistic Terms. Tashkent:. State Scientific Publishing House "UzME",2002, P. 164.

11) Bahadir Gunes. About idioms formed with the word "head" in Azerbaijani Turkish. Bugu Journal of Language and Education,1(2), P. 150-162.

12) Filiz Mete. Teaching idioms as a sign of cultural partnership. Ankara University Faculty of Language, History and Geography Journal of Turcology 21, 2 (2014) P. 113-128.

13) Omer Asim Aksoy. Dictionary of proverbs and idioms. Istanbul, "Inkilap", 2nd book.1993.

14) S.I. Asalieva Lexical-semantic analysis of phraseological units with the "eye / eye" component in English and Russian. Journal "Philological Sciences". Questions of theory and practice. Tambov: 2016. № 1(55): 1. P. 90-94.

15) Yu.V. Milyutina Lexico-semantic analysis of phraseological units with a beat component in Bryansk dialects (Belarusian and Ukrainian).

16) Kuchesheva I.L. Lexico-semantic analysis of proper names in English and Russian phraseological units: linguoculturological approach. ChitGU Bulletin. 3 (48) 2008. P.30-33.

17) H.Berdiyorov, R.Rasulov, B.Yuldashev. Materials from Uzbek phraseology. Sam., Part One, 1976, pp. 4-7.

18) U.Tursunov, J.Mukhtorov, Sh.Rahmatullaev. Modern Uzbek literary language. Tashkent: 1992, P. 74.

19) U.Lafasov. Candidate's dissertation “Expression of subjective modality in dialogic speech". Tashkent: 1996, P. 81-139.

20) A.Gulamov, M.Askarova. Modern Uzbek literary language (syntax). Part 2. Tashkent: “Teacher”1987, P. 26. 